\title{
NONLINEAR BEHAVIOUR OF TWO-WHYTE STONE WALLS
}

\author{
BURCU DINÇ-ŞENGÖNÜL ${ }^{1 *}$, YASIN MURAT HOTHOT ${ }^{2}$, BILGE DORAN $^{2}$, \\ NABI YÜZER ${ }^{2}$, SERHAN ULUKAYA ${ }^{2}$ AND DİDEM OKTAY ${ }^{2}$
}

\author{
${ }^{1}$ Department of Civil Engineering \\ Yıldız Technical University \\ Davutpasa Campus, 34220 Istanbul, Turkey \\ e-mail: bdinc@yildiz.edu.tr, https://avesis.yildiz.edu.tr/bdinc (*corresponding author) \\ ${ }^{2}$ Department of Civil Engineering \\ Yıldiz Technical University \\ Davutpasa Campus, 34220 Istanbul, Turkey \\ email: \{yasinmurathothot@gmail.com,doran@yildiz.edu.tr, nyuzer@yildiz.edu.tr, \\ serhanu@yildiz.edu.tr, dyasar@yildiz.edu.tr \}
}

Keywords: Historical Structure, Masonry, Stone Walls, Nonlinear Behaviour

\begin{abstract}
Engineers work hard to convert the highly uncertain and nonlinear behavior of historic masonry structures into something that can be understood with mathematical certainty. Therefore, practical and also accurate structural analysis techniques are still needed for the preserve the historical monuments as a huge cultural heritage. In this context, determining the mechanical properties of historical walls under in-plane and out-of-plane lateral loadings is one of the most important aim. This study aims to investigate the three dimensional (3D) nonlinear behaviour of stone walls subjected to a combination of lateral and vertical loads using approprate constitutive numerical modeling. For this purpose, a simplified micro modeling approach has been proposed for the $3 D$ nonlinear finite element analysis (NLFEA) of stone wall. The dry-stone masonry wall from the literature has been used in the verification step for the proposed model. After that, the new two-whyte stone wall has been constructed in accordance with the original material characteristics derived from the experimental studies and tested under shear compression. Finally, numerical results of NLFEA and experimental results of walls have been compared. It was observed that the numerical analysis results are well matched with the experimental ones.
\end{abstract}

\section{INTRODUCTION}

Masonry historic structures represent architectural cultural heritage of great historical importance in Turkey. They have been used for public and residential buildings in the past several thousand years. A great number of well-preserved old masonry structures still exist proving that this form of construction can successfully resist loads and environmental impact [1]. Conventionally, most major buildings were solid walled structures with the walls bearing directly on the ground. Historical masonry structures are exposed to horizontal and vertical 
loads and atmospheric influences throughout their entire life. These structures are composed of many layers and due to the weak connections between the weak materials and gaps, the masonry walls in these structures tend to leave the building. For this reason, damages, cracks, gaps may occur as a result of environmental impacts in historical masonry structures and even dangerous situations can occur [2]. Since these damages are directly related to the loads affecting the structure, it is very important to investigate the complex and nonlinear behavior of the structures by numerical analysis [1,3-5].

The primary aim of this study is to present an effective modeling procedure for the stone masonry walls under shear and compression. For this purpose, in the first part of this study, the mechanical properties of stone and mortar samples provided from a historical masonry structure in Turkey have been determined at laboratory conditions. Then, the two-whyte stone wall which have nominal dimensions $1010 \times 1005 \times 280 \mathrm{~mm}$ (lenght $\mathrm{x}$ height $\mathrm{x}$ width) have been constructed in the laboratory of Yildiz Technical University in accordance with the original material characteristics derived from the experimental studies. In order to evaluate the nonlinear behaviour of two-wyhte stone wall, these wall have been tested under shearcompression. Then this experimental study has been modelled in ABAQUS-6.14 package [6]. An experimental study conducted by Lorenco et. al., which involved dry stone masonry walls under a combination of vertical preloading, and in-plane horizontal shear loading has been selected for the verification of the numerical modeling technique. After that, experimental and numerical results of constructed in laboratory were compared.
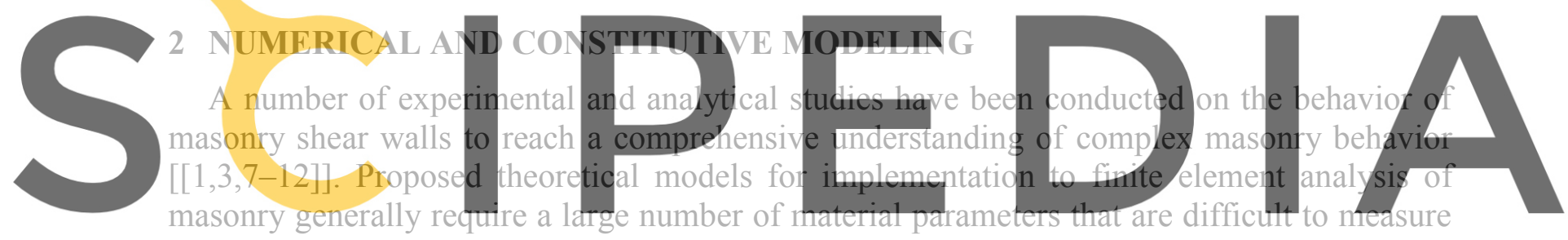

easily and reliably. For this reason, several attempts have been made to express the stress-

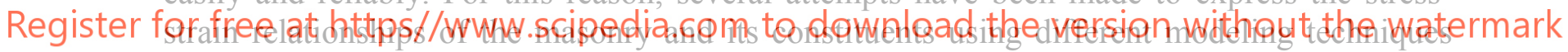

such as micro-modeling, homogenization approach and macro-modeling. The common approach is to treat masonry as a continuous medium with the exception of micro-modeling. Micro-modeling should describe the masonry, mortar and the interaction behavior between them. It has been revealed in literature that micro models are more suitable for modeling small structures and the studies in which the interaction between mortar-stone and/or failure modes are important. On the other hand, in macro models, the structural elements are modeled as homogeneous (brick/stone and mortar are modeled together) and the stress-strain relations and fracture surfaces of these elements are described first. Macro models are more useful for larger structures and when the behavior of the entire structure is investigated. In this study, micro modeling technique is addopted for nonlinear analysis of masonry stone walls.

Multi-axial stress states defines the constitutive behavior of the structures such as masonry walls, RC panels, confined columns or elements beyond the elastic range. The basic elastoplastic constitutive models, i.e Mohr-Coulomb (MC) and Drucker-Prager (DP) are widely adopted in constitutive modeling materials, like concretes, soils and rocks $[4,13]$. Drucker-Prager (DP) yield/break criterion is the most practical mathematical form of the vonMises criterion used for concrete, metal and stone type materials, and takes into account both 
hydrostatic pressure and deviator stress effects at the highest strength (Figure 1)[9]. According to the DP yield criteria, the yield surface can be expressed as follows [6]:

$$
f\left(I_{1}, J_{2}\right)=\alpha \cdot I_{1}+\sqrt{J_{2}}-k=0
$$

where $\alpha$ and $k$ values are material constants and these values depend on the internal friction angle $(\phi)$ and cohesion (c) values in the MC criterion. Internal friction angle $(\phi)$ and cohesion (c) values can be expressed as [6]:

$$
\alpha=\frac{2 \sin \phi}{\sqrt{3}(3-\sin \phi)}, \quad k=\frac{6 c \cos \phi}{\sqrt{3}(3-\sin \phi)}
$$
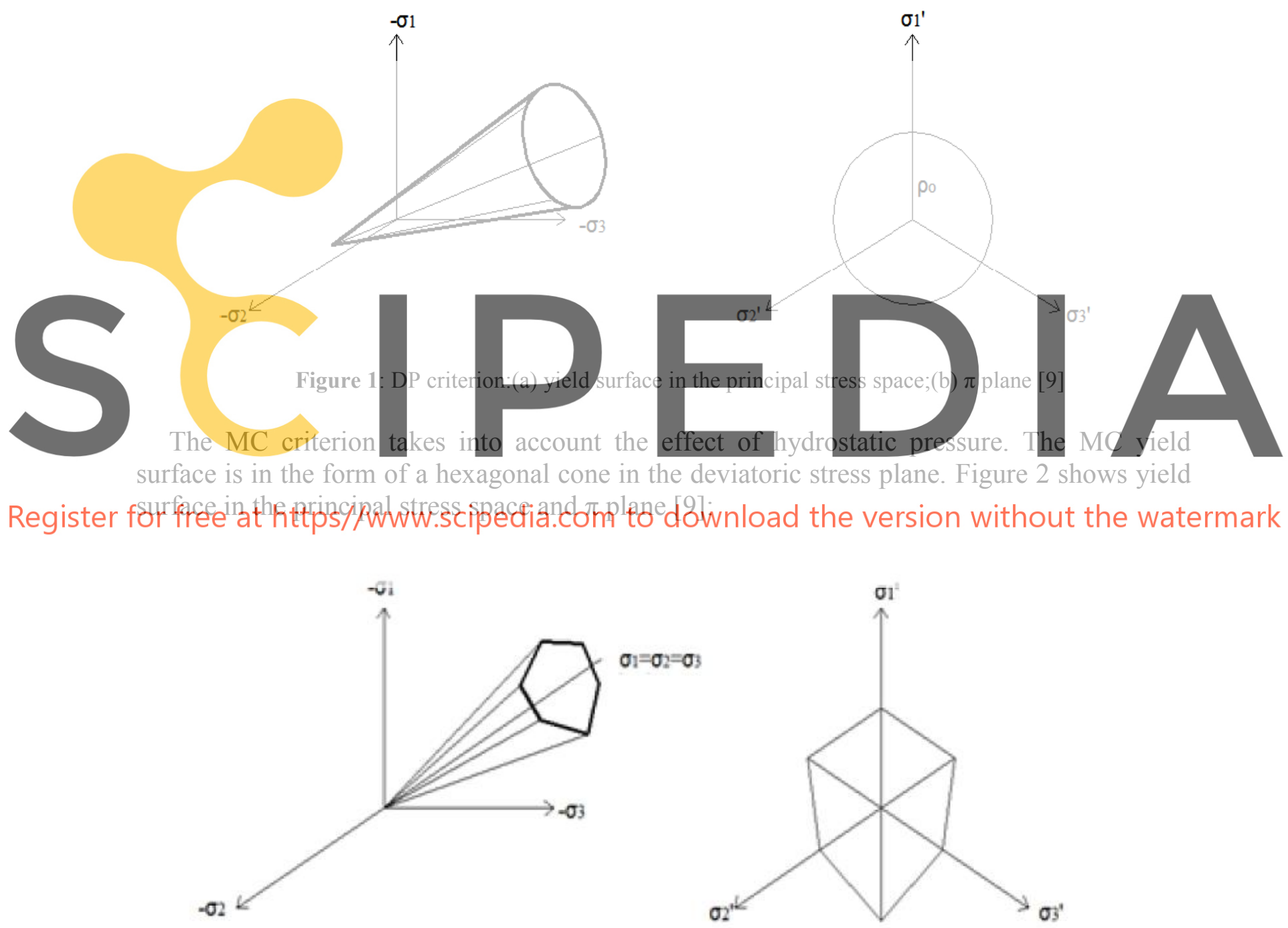

Figure 2: MC criterion:(a) yield surface in the principal stress space;(b) $\pi$ plane [9]

The MC criterion shows the linear envelope curve obtained from the shear strength of the 
material against the applied normal strength [9]. This relationship is expressed as follows [6]:

$$
\tau=c-\sigma \tan (\phi)
$$

where $\tau$ is shear strenght, $\sigma$ corresponds to normal stress which is negative in compression, $\mathrm{c}$ is cohession and $\phi$ is the internal friction angle. From Mohr's circle [6]:

$$
\tau=s \cos \phi \quad \sigma=\sigma_{m}+s \sin \phi
$$

Substituting for $\tau$ and $\sigma$, multiplying both sides by $\cos \phi$, and reducing, the MohrCoulomb model can be written as [6]:

$$
s=\sigma_{m} \sin \phi-c \cos \phi=0
$$

where $s$ is half of the difference between the maximum principal stress, $\sigma_{1}$, and the minimum principal stress, $\sigma_{3}$ (and is, therefore, the maximum shear stress),

$$
s=\frac{1}{2}\left(\sigma_{1}-\sigma_{3}\right)
$$

and $\sigma_{m}$ is the average of the maximum and minimum principal stresses, and $\phi$ is the frictional angel [6]:

$$
\sigma_{m}=\frac{1}{2}\left(\sigma_{1}+\sigma_{3}\right)
$$

\section{SOFTWARE IMPLEMENTATION OF PROPOSED CONSTITUTIVE MODEL}

\section{Three dimensional}

Masonry constituents

obeying DP criterion

Besides, the mortar thicknes

surface interaction while the chinensions of the

of a masonry structure unchanged (Figure
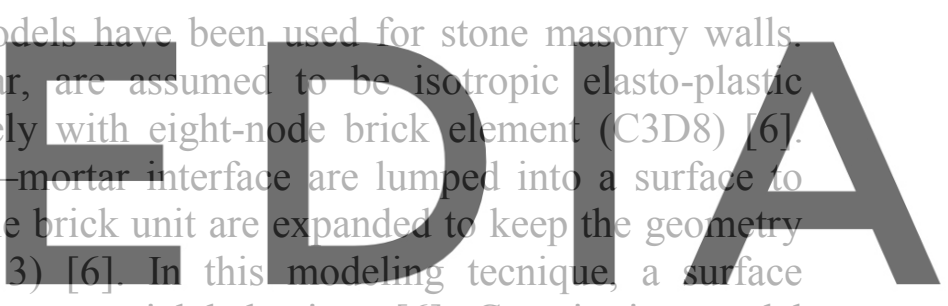

interaction consist of normal behaviour and tangential behaviour [6]. Constitutive model

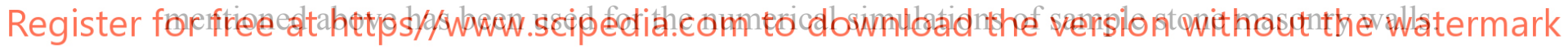
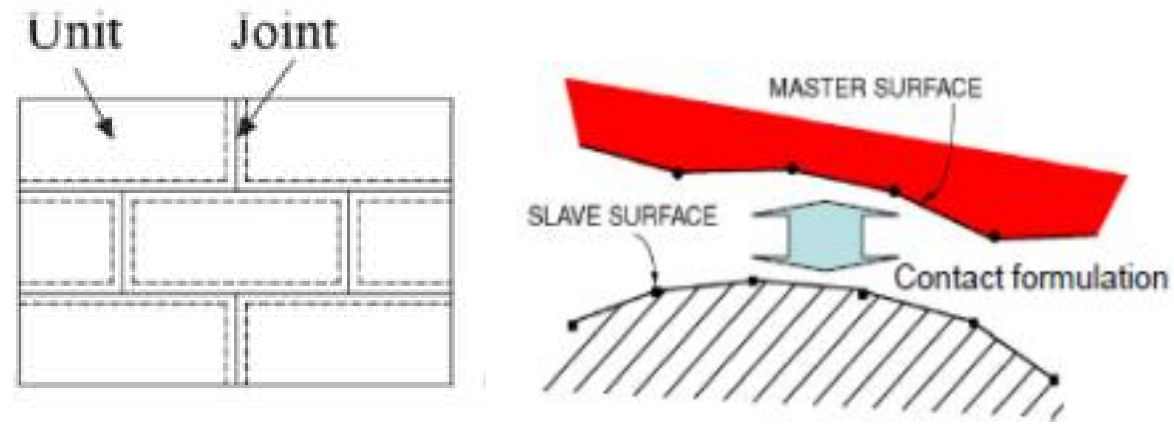

Figure 3: Simplified micro-modeling technique and surface to surface contact [6]

Lourenco et. al. [3], tested 1000x1000x200 mm dry stone masonry walls under a combination of vertical preloading, and in-plane horizontal shear loading (Figure 4). Brick

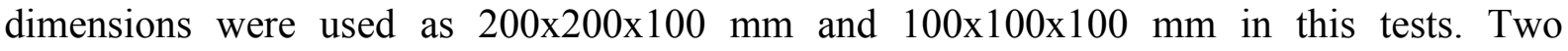
connected hydraulic jacks $(\mathrm{N})$ were placed on the wall while the shear load was applied to the 
wall by a horizontal hydraulic jack (P). In this study, the vertical load levels adopted for the tests were $30,100,200$, and $250 \mathrm{kN}$. These load values lead to compressive normal stresses of $0.15,0.50,1.00$, and $1.25 \mathrm{MPa}$, respectively. A numerical simulation of the tested stone walls was carried out with the Abaqus software [6]. Mechanical properties for test wall and values adopted for FE analyses are given in Table 1, respectively. Both simulation model and laboratory test results agreed very well (Figure 5). Also deformed shape of the experimental and numerical model of the wall was given in Figure 6 [3].

Table 1. Comparison of Experimental and Numerical Parameters

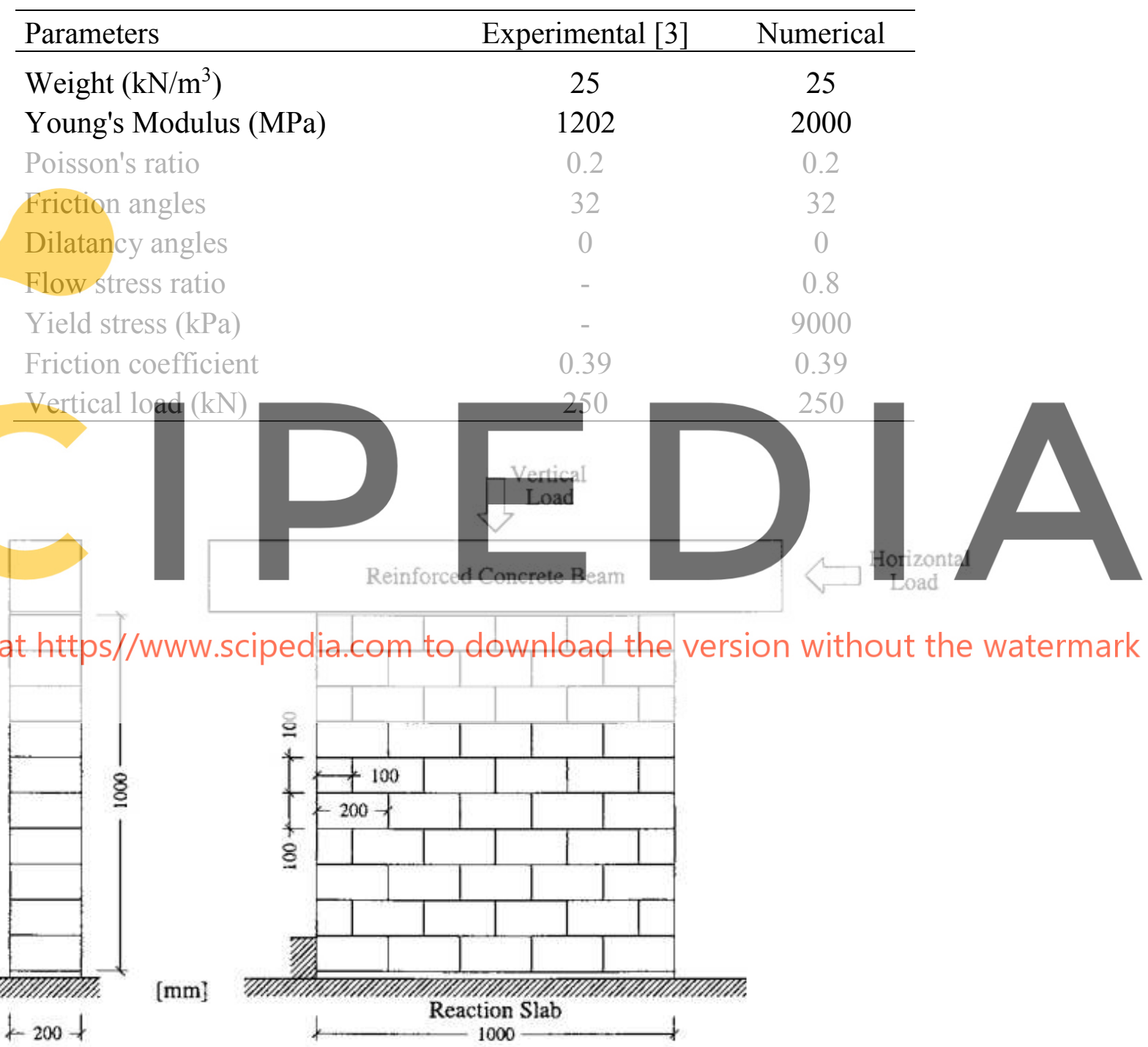

Figure 4: Experimental setup of dry stone masonry wall [3] 


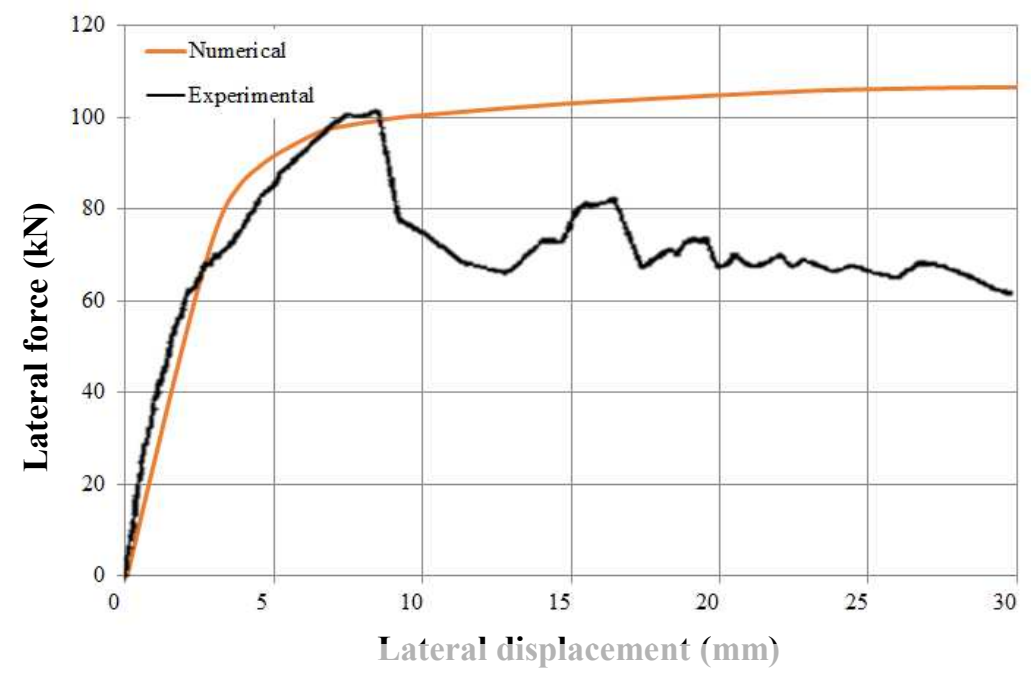

Figure 5: Comparison of experimental and numerical analysis results
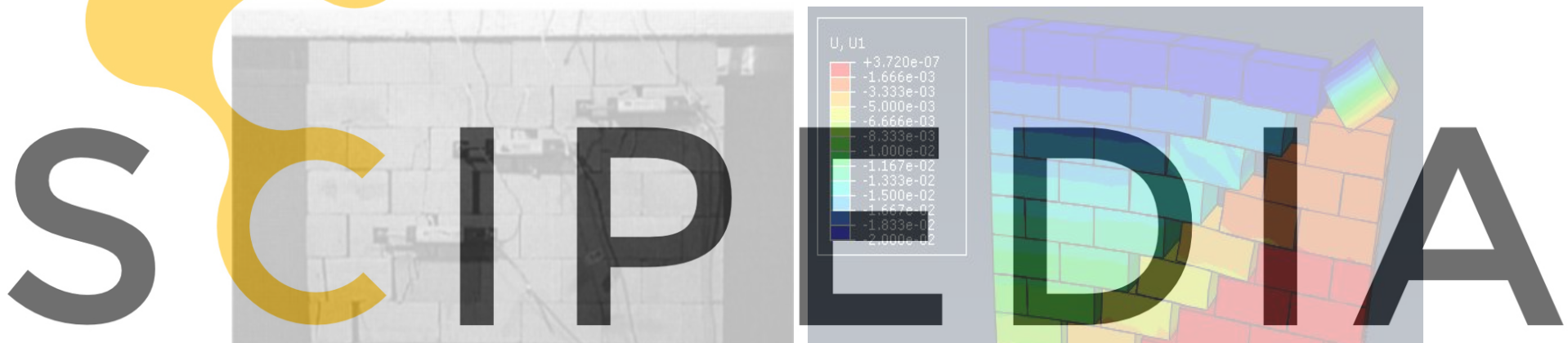

Register for free at https//www.scipedia.com to

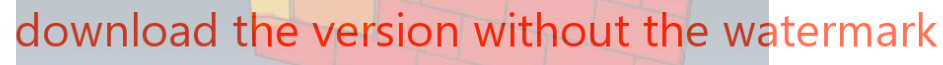

Figure 6: Experimental and numerical comparison of failure mechanism [3]

In the experimental part of this study, the two-whyte stone masonry wall with dimensions of $1010 \times 1005 \times 280 \mathrm{~mm}$ were produced in accordance with the orginal material characteristic (Figure 7). The constituents and mix proportions of produced mortar were selected to be compatible with historical lime based mortar specimens. Mechanical parameters of two-whyte stone masonry wall are given in Table 2 . The specimen sizes used in mechanical experiments for stone (cylindrical) are different from stone which used in the two-whyte masonry stone model wall. Assuming that the increase in size increases defects (cracks, gaps, etc.) in the specimen, Young's modulus and uniaxial compressive strength values have been decreased in numerical analysis (Table 2).

At the 28th day after the construction, the wall was subjected to increasing lateral load under a constant, uniformly distributed vertical load. The loading apparatus consisted of a 
$2000 \mathrm{kN}$ and $500 \mathrm{kN}$ capacities hydraulic rams for vertical and horizontal loading, respectively. Instrumentation included two load cells and four displacement transducers (Figure 8). Vertical pre-compression distributed loading of $1.06 \mathrm{MPa}$ was applied to the top surface of a steel plate with a thickness of $3.5 \mathrm{~cm}$ located on the center of wall. Lateral loading was then applied at a rate of $0.6 \pm 0.1 \mathrm{kN} / \mathrm{s}$. For repairing and strengthening issues, the stone test wall was not loaded to failure (total destruction was not proposed). As shown in Figure 8, when a stair step crack appeared and extended diagonally across the wall, the test was stopped. Finally, experimental and numerical analysis results of two-wyhte masonry wall were compared (Figure 9). Also deformed shape of the numerical model of the two-wyhte masonry wall was given in Figure 10.

Table 2. Experimental and Numerical Parameters of two-whyte stone masonry wall

\begin{tabular}{lcc}
\hline Parameters & $\begin{array}{c}\text { Experimental } \\
\text { (stone brick) }\end{array}$ & $\begin{array}{c}\text { Numerical } \\
\text { (stone brick+mortar) }\end{array}$ \\
\hline Weight $\left(\mathrm{kN} / \mathrm{m}^{3}\right)$ & 25 & 25 \\
Young's Modulus $(\mathrm{MPa})$ & 13000 & 5000 \\
Poisson's ratio & 0.28 & 52 \\
Friction angles & 52 & 10 \\
Dilatancy angles & - & 0.8 \\
Flow stress ratio & - & 10000 \\
Yield stress (kPa) & 49000 & 0.5 \\
\hline
\end{tabular}

Register for free at https//www.scipedia.com to download the version without the watermark

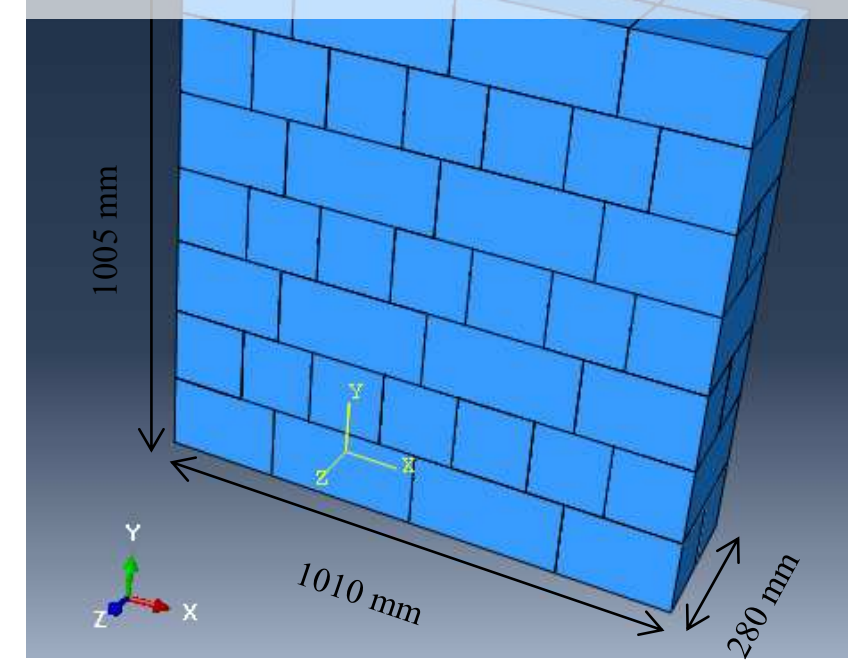

Figure 7: Geometry for the two-whyte stone masonry wall 

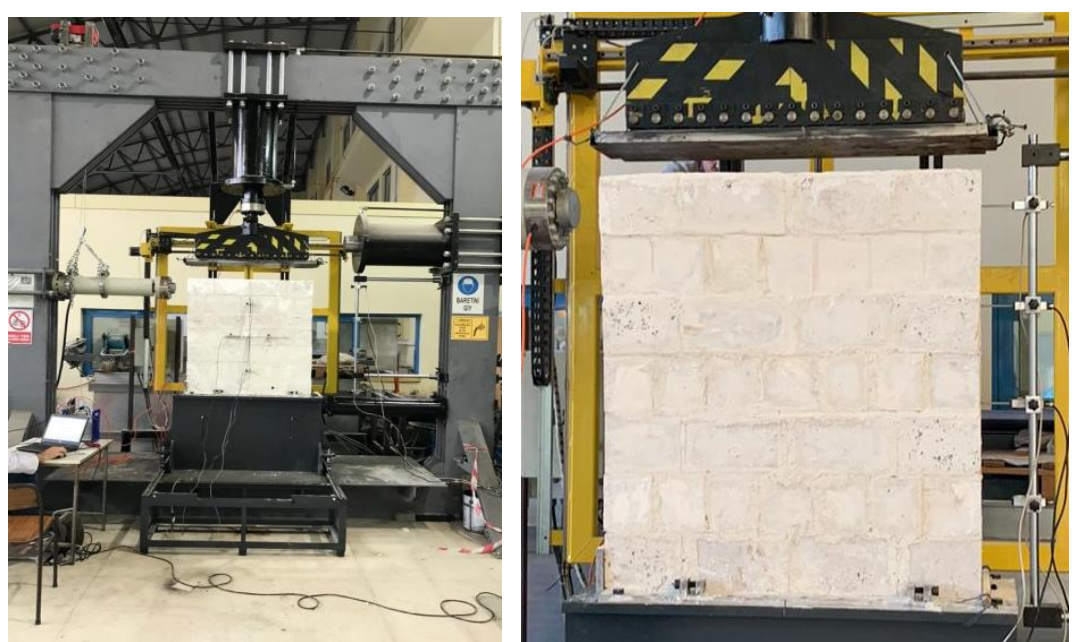

Figure 8: Experimental set-up
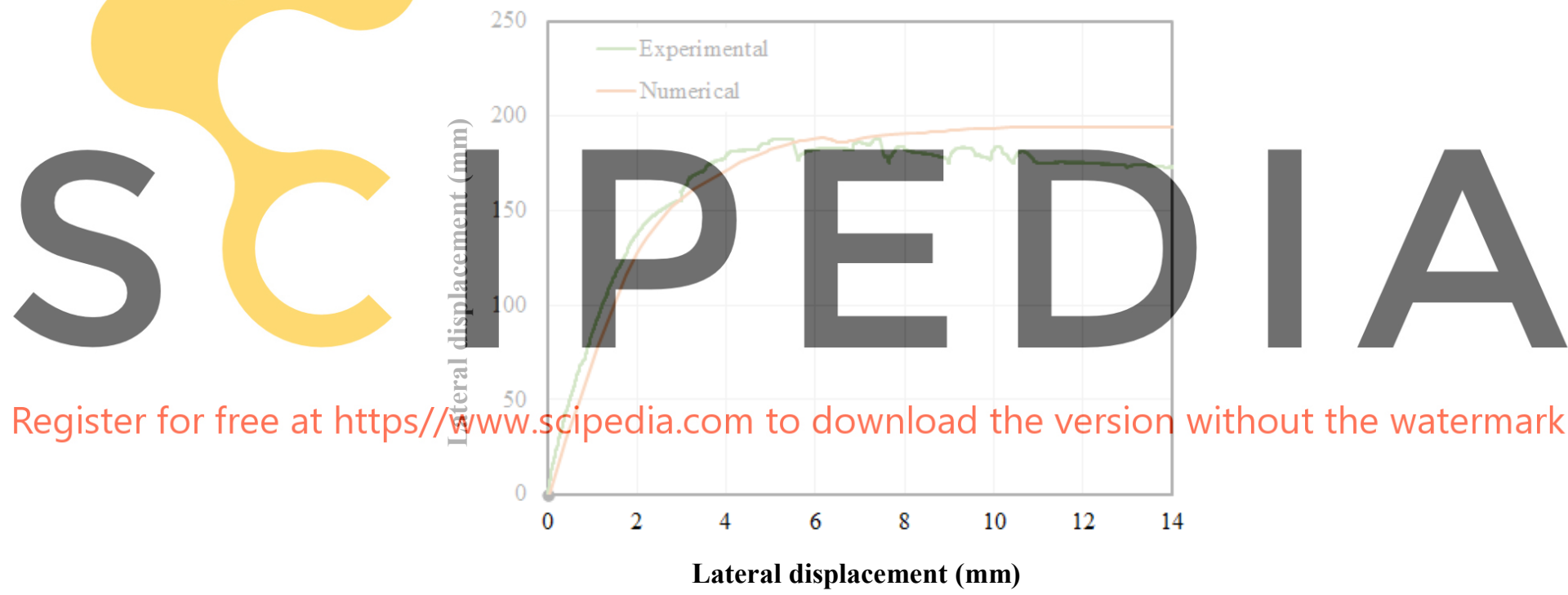

Figure 9: Comparison of experimental and numerical analysis result for two-whyte masonry wall 

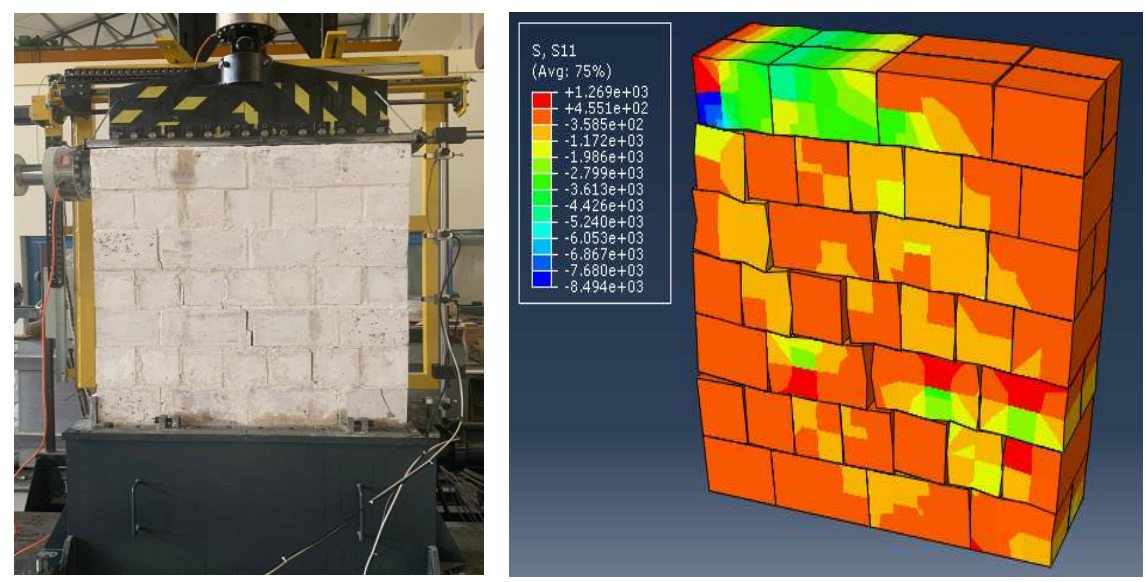

Figure 10: Deformed shape of two-whyte stone wall numerical analysis result

\section{CONCLUSIONS}

In the present paper, Drucker-Prager (DP) type plasticity is proposed to model the in-plane non-linear structural behavior of stone walls. In order to evaluate the accuracy of proposed simplified micro modeling technique, numerical results of a nonlinear finite element analysis (NLFEA) are comparec drawn from the result

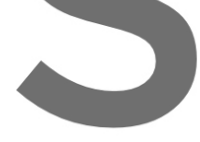
The material parameters of DP criteric considered separately as isotropic and l the cohesion and th with the test results
meters of DP criterio
the internal friction a

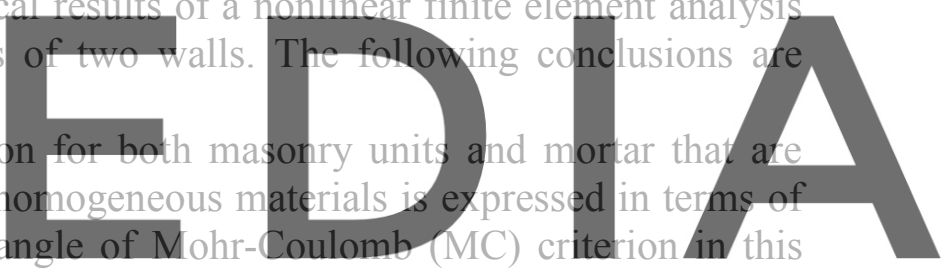
study. Therefore, the surfaces of both DP and MC yield criteria are made to coincide

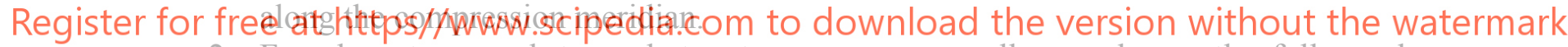

2. For dry stone and two-whyte stone masonry walls, cracks mostly follow along cement mortar joints in a stair step manner.

3. Comparison of the wall responses subjected to vertical and lateral loads between analytical and experimental results, especially for dry stone masonry wall, indicates reasonable agreement except the shape of the load-displacement curves for both mortar joint and dry joint masonry after peak point. The reason for this is that there exists no gradually developing damage defined in the elasto-plastic model.

\section{REFERENCES}

[1] Kömürcü, S., Yığma duvarların düzlem içi kırılma mekanizmalarının nümerik olarak belirlenmesi, (In Turkish), MSc. Thesis, İstanbul Technical University (2018).

[2] Baltazar, L.G., Henriques, F.M.A., Cidade, M.T., Experimental study and modeling of rheological and mechanical properties of NHL grouts, 27 (2015) 1-11. https://doi.org/10.1061/(ASCE)MT.1943-5533.0001320.

[3] Lourenço, P.B., Oliveira, D.V., Roca, P., Orduña, A., Dry joint stone masonry walls 
subjected to in-plane combined loading, J. Struct. Eng. 131 (2005) 1665-1673. https://doi.org/10.1061/(ASCE)0733-9445(2005)131:11(1665).

[4] Bal, İ.E., Yığma yapılarda doğrusal olmayan artımsal analiz için bir yöntem önerisi,(In Turkish) Dicle Üniversitesi Mühendislik Fakültesi Mühendislik Derg. (2017) 463-474.

[5] Milani, G., Lourenço, P.B., 3D non-linear behavior of masonry arch bridges, Comput. Struct. 110-111 (2012) 133-150. https://doi.org/10.1016/j.compstruc.2012.07.008.

[6] D.S. Simulia, Abaqus 6.14, Analysis User's Guide. (2014).

[7] Doran, B., Orhun Koksal, H., Aktan, S., Ulukaya, S., Oktay, D., Yuzer, N., In-Plane shear behavior of traditional masonry walls, Int. J. Archit. Herit. 11 (2017) 278-291. https://doi.org/10.1080/15583058.2016.1207114.

[8] Doran, B., Yuzer, N., Aktan, S., Oktay, D., Ulukaya, S., Numerical Modeling of Traditional Masonry Walls Strengthened with Grout Injection, Int. J. Archit. Herit. 0 (2019) 1-16. https://doi.org/10.1080/15583058.2019.1618970.

[9] Aktan, S., Düzlem İçi Yükler Etkisindeki Yığma Duvarlarda Bünyesel Modelleme, (In Turkish), PhD. Thesis, Yildiz Technical University (2016).

[10] Oliveira, D.V, Lourenço, P.B., Experimental Behaviour of three-leaf stone masonry walls, Conf. Brok. Event Constr. Asp. Built Herit. Prot. (2006) 355-362.

[11] Corradi, M., Tedeschi, C., Binda, L., Borri, A., Experimental evaluation of shear and compression strength of masonry wall before and after reinforcement: Deep repointing, Constr. Build. Mater. $22 \quad$ (2008) 463-472.

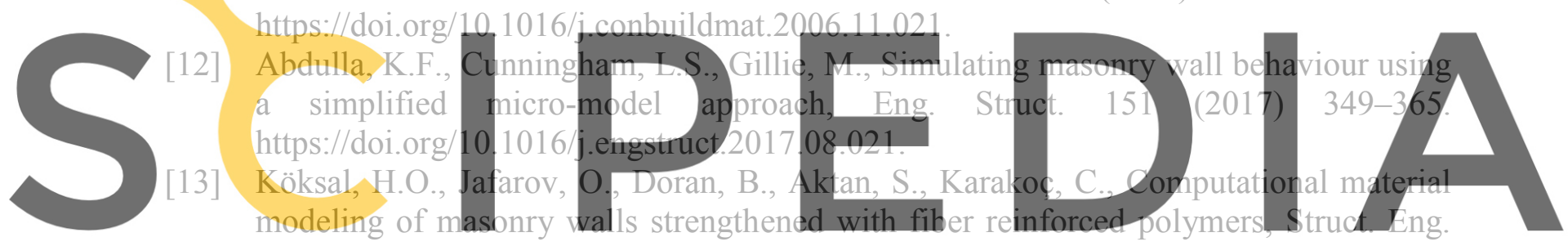
Mech. 48 (2013) 737-755. https://doi.org/10.12989/sem.2013.48.5.737. 